\title{
MATURATION STAGES OF FRUITS AND PHYSIOLOGICAL SEED QUALITY OF Physalis ixocarpa BROT. EX HORMEN ${ }^{1}$
}

\author{
NATÁLIA DOS SANTOS BARROSO ${ }^{2}$, MANUELA OLIVEIRA DE SOUZA ${ }^{3}$ \\ LAURA CAROLINA DA SILVA RODRIGUES ${ }^{4}$, CLAUDINÉIA REGINA PELACANI ${ }^{5}$
}

\begin{abstract}
Physalis is represented by species that produce fruits with relevant potential for national and international marketing. The species are normally grown from seeds, so maturation studies are important to assist the point of harvest, as well as seeds with a high physiological potential, since the fruits remain enclosed within a cup throughout their development. Despite the nutraceutical importance of fruits and medicinal potential of many species of Physalis information on the physiological seeds quality are scarce. This study aimed to monitor the physical and physiological changes of maturation and the viability of seeds during fruit development stages. The fruits of $P$. ixocarpa were collected in 15, 25, 35, 45, 55 days after anthesis (DAA). Length, diameter, fresh weight, skin and cup coloring characterization, TSS content, number and weight of seeds per fruit were obtained at each development stage. We also evaluated and correlated the coloring and pigment content of the cup (chlorophyll $a$ and $b$ ). Water content, dry matter weight and germination rate were measured from fresh and dry seeds (room conditions, 72 hours). The main physical and physiological changes during maturation occurred within 35 DAA. The maximum physiological seeds quality was achieved within 45 DAA when the cup is completely or partially broken with coloring between yellowish-green and light-yellowish-brown and the ripe fruit in dark-green.
\end{abstract}

Keywords: sowing, point of harvest, seeds weight, GSI.

\section{MATURAÇÃO DE FRUTOS E QUALIDADE FISIOLÓGICA DE SEMENTES DE Physalis ixocarpa BROT. EX HORMEN}

RESUMO: Physalis é representado por espécies que produzem frutos com relevante potencial de comercialização nacional e internacional. As espécies são normalmente cultivadas a partir de sementes, e estudos de maturação são importantes para auxiliar na obtenção do ponto de colheita e de sementes com elevado potencial fisiológico, visto que os frutos permanecem encerrados dentro de um cálice durante todo o seu desenvolvimento. Apesar da importância nutracêutica dos frutos e do potencial medicinal de muitas espécies de Physalis, informações sobre a qualidade fisiológica de sementes são escassas. Este trabalho teve como objetivo acompanhar as mudanças físicas e fisiológicas da maturação e a viabilidade das sementes durante os estádios de desenvolvimento do fruto. Os frutos de P. ixocarpa foram coletados aos 15, 25, 35, 45, 55 dias após a antese (DAA). Em cada estádio de desenvolvimento foi obtido o comprimento, diâmetro, peso fresco, caracterização da coloração da casca e do cálice, teor de SST, número e peso de sementes por fruto. Foram também avaliados e correlacionados a coloração e o teor de pigmentos (clorofilas $a$ e $b$ ) do cálice. As sementes frescas e dessecadas (condições ambiente, $72 \mathrm{~h}$ ) foram avaliadas quanto ao conteúdo de água, peso da matéria seca e taxa de germinação. Observou-se que as principais mudanças físicas e fisiológicas na maturação ocorreram até 35 DAA. A máxima qualidade fisiológica das sementes foi alcançada aos 45 DAA, indicando que a melhor época de coleta é quando o cálice encontra-se completamente ou parcialmente rompido, de coloração verde-amarelado a marrom-amarelado-claro e os frutos maduros de coloração verde-escuro.

Termos de indexação: semeadura, ponto de colheita, peso de sementes, IVG.

\footnotetext{
1(Paper 263-15). Received November 17, 2015. Accepted July 19, 2016.

${ }^{2}$ Ph.D. student in Plant Genetic Resources in the State University of Feira de Santana. E-mail: nataliasbarroso@yahoo.com.br ${ }^{3}$ Ph.D. in Biotechnology, adjunct professor in Federal University of Recôncavo of Bahia. E-mail: manuelasouza@ufrb.edu.br ${ }^{4}$ Graduate student in Agronomy in the State University of Feira de Santana. E-mail: lauracrodrigues@hotmail.com.br

${ }^{5} \mathrm{Ph} . \mathrm{D}$. in Agricultural Sciences, full time professor in the State University of Feira de Santana. E-mail: claudineiapelacani@gmail.com
} 


\section{INTRODUCTION}

Physalis is highlighted as a genus with diverse potential and biotechnological uses (DKHIL et al., 2014; FISCHER et al., 2014), especially fruits of Physalis ixocarpa, which in the Brazilian horticulture scenario may be present as exotic and with an aggregate and significant market value.

In Mexico commonly known tomatillo, 'tomate de cascara' and 'tomate verde', the $P$. ixocarpa fruits are widely used in the popular cuisine like salads, soups, stews and green sauces, being so far the most extensively cultivated species in this country, which represents a valuable food, medicinal and economic resource (SANTIAGUILLOHERNANDEZ; YANEZ, 2009). Published data have shown that besides being sources of essential nutrients to human health, such as vitamin $\mathrm{C}$ and B3, carbohydrates, proteins and minerals (BOCK et al., 1995). The ethanol extract of the fruit was active against Staphylococcus aureus (KHAN et al., 2016) and showed chemo-preventive activity (MALDONADO et al., 2011). This information showed the need for more accurate studies related to the farming, especially the fruit maturation peculiarities and seeds viability of that species used as a starting point for further investigations, as well as new discoveries of their potential.

Studies have been performed aiming to understand the answers to the stress, storage, conservation and identification of the best moment of harvest to obtain vigorous seeds of $P$. ixocarpa due to the fact that its spread occurs mainly by seeds (CALZADA-LOPEZ et al., 2014; PICHARDOGONZÁLEZ et al., 2014).

However, species that shows flowering and fruiting occurring discontinuously as $P$. ixocarpa make difficult and sometimes impossible to anticipate the ideal point of the fruit harvest and the physiological seeds maturation, since the same plant shows fruits in different stages of maturation (JUSTINO et al., 2015).

Information on obtaining and production of $P$. ixocarpa seeds are scarce even its being an important aspect for the success of a culture. Thus, studies are necessary to identify and compare the main changes during maturation of fruits in order to determine a harvest index for seeds production in high level.

Thus, the main purpose of this study was to monitor and determine the physiological seeds maturation of $P$. ixocarpa during development and maturation of the fruit trying to predict the best harvest moment.

\section{MATERIALS AND METHODS}

\section{P. ixocarpa farming}

Experiments were carried out from April to August 2014 at the Horto Florestal Experimental Unit of the State University of Feira de Santana (UEFS), BA, Brazil, located at $12^{\circ} 16^{\prime} 00^{\prime \prime}$ south latitude and $38^{\circ} 58^{\prime} 00^{\prime \prime}$ west longitude, showing altitude of 234 meters. The regional climate is dry sub-humid, mega-thermal (C2rA'a') with average temperature at $24{ }^{\circ} \mathrm{C}$ and average rainfall around $848 \mathrm{~mm}$ annual, according to the classification of Thornthwaite and Matther (1955) (Climatological station of UEFS, 2015).

Seeds from the previous year grown in the same location were used for seedlings production. Sowing occurred in plastic containers of $300 \mathrm{ml}$ completed with a commercial substrate $\left(\right.$ Plantmax $\left.^{\odot}\right)$ placed in a greenhouse and under irrigation by microsprinkler. Thinning was performed after emergence and expansion of cotyledons by keeping a seedling per container until the transplanting with an average of 15 to 20 days after sowing, when seedlings show the first couple of eophylls. Before transplanting, the pits ( $15 \mathrm{~cm}$ deep) received $50 \mathrm{~g}$ of organic fertilizer. Sixty seedlings of $P$. ixocarpa were arranged in five lines, spaced $0.8 \mathrm{~m}$ between plants and $2.0 \mathrm{~m}$ between lines.

The staking of air branches were performed in $\mathrm{X}$ format during farming according to the recommendations of Muniz et al. (2011). Dripper spaced every $0.8 \mathrm{~m}$ were used as irrigation system. Emulsifiable oil solution (1\%) of a commercial neem was used for pests controlling, which was diluted in water in a portion of $5 \mathrm{~mL} \mathrm{~L}^{-1}$, applied with hand sprayer in the beginning of plant development, when a higher incidence of pest attack was observed.

During flowering stage, from the anthesis (flower opening) an average of eight flowers per plant was identified, then, the fruit development was monitoring. The identification period did not exceed 15 days cultivation at that stage.

\section{Physical-chemical analysis and fruit maturation}

The physical-chemical analysis was performed by a set of fruit + cup collected with five (5) stages of development, corresponding to 15, 25, 35,45 and 55 days after anthesis (DAA). At each stage 50 fruits were randomly harvested in different positions from the plant. A color chart RHS (THE ROYAL HORTICULTURAL SOCIETY, 2001) was utilized to determine the predominant colors of the fruits skin and cup. The weight average of the fresh 
weight $(\mathrm{g})$, the transverse diameter (measured in the middle portion of the fruit), and longitudinal (measured from apex to base) of the fruit ( $\mathrm{mm}$ ) were used for sampling through an analytical balance known as Shimadzu AY220 (0.001g) and digital caliper of Cosa brand $(0.01 \mathrm{~mm})$, respectively. The total soluble solids (TSS) was indirectly measured by placing a fruit juice drop in the manual refractometer prism of Atago brand in a temperature correction of $20{ }^{\circ} \mathrm{C}$ and expressed in ${ }^{\circ}$ Brix. After that analysis, a randomized sample was performed consisting of five repetitions and each one was represented by 10 fruits. An average number and seeds weight per fruit were defined after processing and drying.

The cup coloring was related with the content of chlorophylls $a$ and $b$ and carotenoids. The pigments were extracted by using dimethyl sulfoxide (DMSO P.A.) and analyzed in triplicate. Six foliar discs of known field were removed from the cup, immersed in screw-tubes containing $5 \mathrm{~mL}$ of the organic extractor. The tubes were in dark and in ambient temperature conditions for approximately 48 hours according to methodology adapted by Cruz et al. (2007). Absorbances were read in Bel Spectro S05 in lengths of 480, 649 and $665 \mathrm{~mm}$. Another six discs, with the same surface were used to determination of weight dry matter (DM). The content of chlorophyll $a$ and $b$, and carotenoids ( $\left.\mathrm{mg} \mathrm{g}^{-1}\right)$ were determined according to the equations proposed by Wellburn (1994).

\section{Physiological seeds quality}

The water content of seeds was defined in two moments after harvest: a) when recently taken from the fruits (fresh seeds) and b) after drying for 72 hours at ambient condition. Dry seeds remained separated in Eppendorf, packed in glass pots at a temperature of $5^{\circ} \mathrm{C} \pm 1$ to obtain seeds in all evaluated stages. The measured water content was based by ISTA (2007) to each maturation stage (DAA) 200 seeds ( 50 seeds by repetition) incubated at $103 \pm 2{ }^{\circ} \mathrm{C}$ for $17 \pm 1$ hours at air circulation. The difference between initial and final weight was used to calculate water content (\%).

The seeds viability in different stages of development and two conditions after seeds harvest (fresh and dry) was determined by germination test performed in controlled conditions of temperature and photoperiod determined for other species of Physalis (SOUZA et al., 2011; 2014). The tests were carried out in chambers with photoperiod of 12 hours adjusted in alternating temperature of $20-30^{\circ} \mathrm{C}$ for 21 days. Daily evaluations were performed and seeds that produced radicle with at least $2 \mathrm{~mm}$ long were considered germinated. At the end of the test, the germination curves were compared at different stages of development, the average time (AT) and the germination speed index (GSI) of fresh and dry seeds.

The germination test was randomized with 4 replicates of 24 seeds. Shapiro-Wilk and Levene tests were used for testing data for normality and homogeneity, being transformed with arcsine $\sqrt{ }(\mathrm{x} / 100)$ when applied. Data were submitted to variance analysis and Tukey test at $5 \%$ of probability was used for comparison between the averages. The data was statistically analyzed using the SISVAR software (FERREIRA, 2011).

\section{RESULTS AND DISCUSSION}

The fruits of $P$. ixocarpa showed significant growth in length and diameter within 35 days after anthesis (DAA), achieving an average of 34.5 and $42 \mathrm{~mm}$, respectively. From this period any investment in the fruit growth does not differ significantly from later stages (Table 1). The results are similar to the higher values obtained by varieties of $P$. ixocarpa evaluated by Rodríguez-Burgos et al. (2011). Analyzing the length and diameter data we observed that the increase of these characteristics occurs simultaneously with the fruit maturation, which was also observed by Cantwell et al. (1992) who accompanied the growth of $P$. ixocarpa fruits. Sbrussi et al. (2014) also observed the similar result during maturation of $P$. peruviana fruits.

The weight of fresh fruits showed the same growth trend observed in the analysis of length and diameter (Table 1) not showing significant differences within $35 \mathrm{DAA}$ and in the following stages. Since the anthesis, the increase in the weight of fresh fruits occurred continuously from $7.4 \mathrm{~g}$ to $34.2 \mathrm{~g}$, an increase of almost five times the initial weight in just three weeks of growth. Similar results were observed by Cantwell et al. (1992) and Rodriguéz-Burgos et al. (2011) working with same species.

According to Aizat et al. (2014), the starch stored in the fruits was hydrolyzed during maturation process, which increases the soluble solids content. This characteristic is very important for the majority species of Physalis, especially those that are consumed often fresh. The content of soluble solids in fruits of $P$. ixocarpa after 35 DAA showed values approximately $5{ }^{\circ}$ Brix (Table 1 ) and were similar to those reported for the species, ranging between 5 to 6.5 ${ }^{\circ}$ Brix according to Cruz-Álvarez et al. (2012) and Jiménez-Santana et al. (2012). The values found were lower than those obtained for other species of Physalis, e.g. P. peruviana whose mature fruit 
reached 13-14 ${ }^{\circ}$ Brix (RODRIGUES et al., 2014) and P. angulata with $12^{\circ}$ Brix (OLIVEIRA et al., 2011). Differently from species of Physalis described before, P. ixocarpa fruits are used as vegetables with similar purposes of the tomato (Solanum lycopersicum). In general, TSS values in tomato plant vary around 5 ${ }^{\circ}$ Brix (ARAUJO et al., 2014) showing that the value found in the study is according to the expected for mature fruits used as vegetables.

According to data in Table 1, fruits of $P$. ixocarpa intended for consumption and processing can be harvested within 35 days of development, which showed the highest weights and physical measurements of growth, besides the maximum value of ${ }^{\circ}$ Brix.

No changes were observed during maturation of fruit skin coloring of $P$. ixocarpa. Different that other species of Physalis, the fruits of P. ixocarpa remains green during all the development period, differing only in green intensity color. A color changing was observed in the beginning of the development, from dark green color (144A-RHS) to yellowish-green (145A-RHS) as it achieved the last stage of maturation (55 DAA) (Figure 1).

According to Cantwell et al. (1992) the content of chlorophyll and carotenoid in the pulp decreases with the development and these pigments are related to changes in the green intensity along during the maturation of $P$. ixocarpa fruits. The same trend pigment decrease was observed when comparing the cup color with chlorophylls contents; cup color changed from yellowish-green (145A-RHS) with 35 DAA, to partially light-yellowish-brown (158A-RHS) with 45 DAA, ending the maturation with the cup predominantly light-yellowish-brown and crumbly appearance (55 DAA) (Figure 2). This breaking characteristic of the cup can be attributed to higher measures of length and diameter of the fruits obtained at this stage (Table 1). The pigment quantity in the cup is inversely proportional to the increase of weight in fresh fruits (Tables 1 and 2), showing higher contents in the early stages and decreasing too fast in the last three stages of maturation, indicating the cup participation in the production, and probably in the partitioning of assimilated for mass increases during the fruit development.

One of the species characteristics belonging to Physalis genus is the presence of the cup acting as a protective structure until its dehydration color changing and small disruptions indicating for the majority of the species at harvest of ripe fruit (BALAGUERA-LOPEZ et al., 2014). P. ixocarpa shows changes in the cup much more pronounced than the color of the fruits, different from P. angulata and P. peruviana, which have a completely brownish and orange color at the time of harvest (CARVALHO et al., 2014; SBRUSSI et al., 2014).

No significant differences were observed between development stages for the number of seeds produced, showing vary between 221 and 270 seeds per fruit (Table 1). Although the number of seed is a characteristic genetically determined by species, the weight reached during the development stages is a result of nutritional and physiological conditions of the plant. During embryogenesis and seed development there is a great demand of assimilated, which in the final phase of maturation corresponds to the maximum weight of the seeds, due to the complete formation of the embryonic axis and endosperm tissue. As shown in Table 1, $P$. ixocarpa seeds reached the highest weight during the last three maturation stages (35 to 55 DAA), with approximately 503, 419, and $474 \mathrm{mg}$, respectively, without differences between them, but with falling trend in the advanced stage of maturity. RodriguezBurgos et al. (2011) found similar results in ripe fruit of Quetaro and Mahone variety of $P$. ixocarpa, with $0.555 \mathrm{~g}$ and $0.515 \mathrm{~g}$, respectively.

As shown in Figure 2, the dry weight of the seeds has increased rapidly in the early stages of development. This result was observed in both fresh and dry seeds. With 35 DAA, the dry matter accumulation occurred slowly in the seeds, reaching the maximum of reserves deposition within 45 DAA, coinciding with reductions of water content, which characterizes the desiccation phase, and preparation for trophic links interruption with the mother plant. Physiologically, this would be the seed harvest point in their maximum physiological quality. However, the seeds of Physalis are inserted in fleshy fruits, and water content reductions shall only occur after seeds withdrawal and processing (CARVALHO et al., 2014; PÉREZ-CAMACHO et al., 2008). Seeds of $P$. ixocarpa reached the maximum dry weight with high water content, between $30-50 \%$, in such circumstances, the metabolism remains active, and a seed deterioration process can start if not promptly harvested (KONG et al., 2014). Thus, the delay in fruits harvesting may lead to the decrease of physiological seeds potential, causing damage in vigor and longevity.

Changes in the water content occurred inversely to dry matter accumulation. The moisture content of the seeds decreases as the fruits and seeds have matured, both in fresh seeds as in dry one (Figure 2). As expected, fresh seeds showed a high water content at the beginning of development, reaching $90 \%$ and with reduction of $40 \%$ until the 
last stage of maturation. Generally seeds harvested with high water content deserve close attention when we want to maintain longevity and vigor. The final drying shall be gradually to avoid membrane damage before storage. Pérez-Camacho et al. (2008) observed a fast reduction in humidity between 35 and 42 days after flowering for $P$. ixocarpa, and the maintenance of humidity around $45 \%$ up to the final evaluated stage. According to these results, although there are significant reductions in water content, it is still high in fresh seed of $P$. ixocarpa, even in the last evaluated stages (Figure 2A).

Values below $9 \%$ for water content of dry seed at stage from 25 to 55 DAA (Figure 2B) are close to the used as reference for the maintenance of physiological and germinative capacity (WALTERS, 2015). These data are important for making decisions of seeds drying methods for conservation purposes. According to the development stage of Physalis seeds the low water content had an increase of germination capacity, keeping the physiological potential and decreases the loss of viability (CARVALHO et al., 2014; PEREZ-CAMACHO et al., 2008; SOUZA et al., 2014).

P. ixocarpa seeds showed some germination potential 25 days after anthesis and higher values were observed with $45 \mathrm{DAA}$, at the same period that seeds reached maximum weight and physiological maturity. The lowest seeds germinated rate in the early stages occurred because of the embryonic axis immaturity which seeds are still investing in tissue formation and probably does not acquired desiccation tolerance capacity, because it would be accumulating reserves to be used during the germination process. According to Perez-Camacho et al. (2008) the increase in desiccation tolerance capacity occurs in the final stages of $P$. ixocarpa seed development, likely when sugar content is high and intracellular membranes stabilization, improving the embryo's performance during germination. Figure 3 shows that 45 DAA point of physiological maturity, the relative frequency of germination was found to the left showing unimodal peak at greater speed and uniformity of germination of $P$. ixocarpa. These results are related to vigor and germination rate and are important parameters of comparison when your goal is to conserve seeds and to use them at other times.

The pre-drying of seeds had no influence in the germination rate when related to an advanced stage of development (Figure 2). However, it provided a quite germination, reaching $70 \%$ of total (Figure 3). Perez-Camacho et al. (2008) observed similar results, in which drying increased the seed germination capacity of $P$. ixocarpa from 28 days to 63 days after flowering.

Seeds remained fresh have decreased in average time (AT) and increased in germination speed index (GSI) with the seeds development, where AT of 2.4 days and GSI of 11.5 days were the best results obtained within 55 days after anthesis (Table $3)$. As for dry seed, the AT of 6.2 days decreased to 2.4 days, when stages of 35 and 55 DAA were compared. The higher GSI was observed in the last two stages of development, achieving approximately 11 and 10.9 days, respectively. The results confirmed the physiological seed quality of $P$. ixocarpa with 45 DAA, reflecting the higher seed vigor and the similarity to those observed by Perez-Camacho et al. (2008) in which the highest speed indexes were obtained in harvested seeds with 42 days of flowering.

TABLE 1- Length (L), diameter (D), fresh weight (FW), content of total soluble solids (TSS), seed weight (SW) and number of seeds (NS) in different stages of development of P. ixocarpa fruits.

\begin{tabular}{ccccccc}
\hline DAA & $\begin{array}{c}\mathrm{L} \\
(\mathrm{mm})\end{array}$ & $\begin{array}{c}\mathrm{D} \\
(\mathrm{mm})\end{array}$ & $\begin{array}{c}\text { FW } \\
(\mathrm{g})\end{array}$ & $\begin{array}{c}\text { TSS } \\
\left({ }^{\circ} \text { Brix }\right)\end{array}$ & $\begin{array}{c}\text { SW } \\
(\mathrm{mg})\end{array}$ & NS \\
\hline 15 & $21.9 \mathrm{c}$ & $25.8 \mathrm{c}$ & $7.50 \mathrm{c}$ & $2.4 \mathrm{~b}$ & $87.7 \mathrm{c}$ & $241 \mathrm{a}$ \\
25 & $29.0 \mathrm{~b}$ & $36.4 \mathrm{~b}$ & $20.8 \mathrm{~b}$ & $3.2 \mathrm{~b}$ & $282.3 \mathrm{~b}$ & $243 \mathrm{a}$ \\
35 & $34.5 \mathrm{a}$ & $42.0 \mathrm{a}$ & $34.2 \mathrm{a}$ & $4.6 \mathrm{a}$ & $502.6 \mathrm{a}$ & $271 \mathrm{a}$ \\
45 & $33.8 \mathrm{a}$ & $44.2 \mathrm{a}$ & $37.4 \mathrm{a}$ & $5.1 \mathrm{a}$ & $419.2 \mathrm{a}$ & $221 \mathrm{a}$ \\
55 & $35.9 \mathrm{a}$ & $44.0 \mathrm{a}$ & $38.3 \mathrm{a}$ & $5.0 \mathrm{a}$ & $474.1 \mathrm{a}$ & $250 \mathrm{a}$ \\
\hline
\end{tabular}

$\mathrm{DAA}=$ days after anthesis. Averages followed by the same letter in the column, for each variable analyzed, do not differ by Tukey test, $5 \%$ of probability. 
TABLE 2 - Content of chlorophyll $a, b$, total and carotenoids of cups of $P$. ixocarpa fruits in different stages of development.

\begin{tabular}{ccccc}
\hline DAA & Chl $a\left(\mathrm{mg} \mathrm{g}^{-1}\right)$ & $\mathrm{Chl} b\left(\mathrm{mg} \mathrm{g}^{-1}\right)$ & Carot $\left(\mathrm{mg} \mathrm{g}^{-1}\right)$ & Chl total \\
\hline 15 & $1.60 \mathrm{c}$ & $0.97 \mathrm{~b}$ & $0.35 \mathrm{~b}$ & $2.58 \mathrm{~d}$ \\
25 & $1.82 \mathrm{c}$ & $0.99 \mathrm{~b}$ & $0.38 \mathrm{~b}$ & $2.82 \mathrm{~cd}$ \\
35 & $1.06 \mathrm{bc}$ & $0.50 \mathrm{a}$ & $0.17 \mathrm{a}$ & $1.56 \mathrm{bc}$ \\
45 & $0.36 \mathrm{ab}$ & $0.20 \mathrm{a}$ & $0.19 \mathrm{a}$ & $0.55 \mathrm{ab}$ \\
55 & $0.09 \mathrm{a}$ & $0.26 \mathrm{a}$ & $0.07 \mathrm{a}$ & $0.35 \mathrm{a}$ \\
\hline
\end{tabular}

$\mathrm{DAA}=$ days after anthesis. Averages followed by the same letter in the column, for each variable analyzed, do not differ by Tukey test, $5 \%$ of probability.

TABLE 3 - Average time (AT) and germination speed index (GSI) of fresh and dry seeds in different stages of development of P. ixocarpa fruits.

\begin{tabular}{ccccc}
\hline \multirow{2}{*}{ DAA } & \multicolumn{2}{c}{ Fresh seeds } & \multicolumn{2}{c}{ Dry seeds } \\
& AT & GSI & AT & GSI \\
\hline 15 & 0.00 & 0.00 & 0.00 & 0.00 \\
25 & $10.37 \mathrm{~d}$ & $0.43 \mathrm{~d}$ & 0.00 & 0.00 \\
35 & $7.84 \mathrm{c}$ & $3.27 \mathrm{c}$ & $6.20 \mathrm{~b}$ & $4.36 \mathrm{~b}$ \\
45 & $5.62 \mathrm{~b}$ & $5.22 \mathrm{~b}$ & $2.26 \mathrm{a}$ & $10.96 \mathrm{a}$ \\
55 & $2.36 \mathrm{a}$ & $11.54 \mathrm{a}$ & $2.36 \mathrm{a}$ & $10.85 \mathrm{a}$ \\
\hline
\end{tabular}

$\mathrm{DAA}=$ days after anthesis. Averages followed by the same letter in the column, for each variable analyzed, do not differ by Tukey test, $5 \%$ of probability.
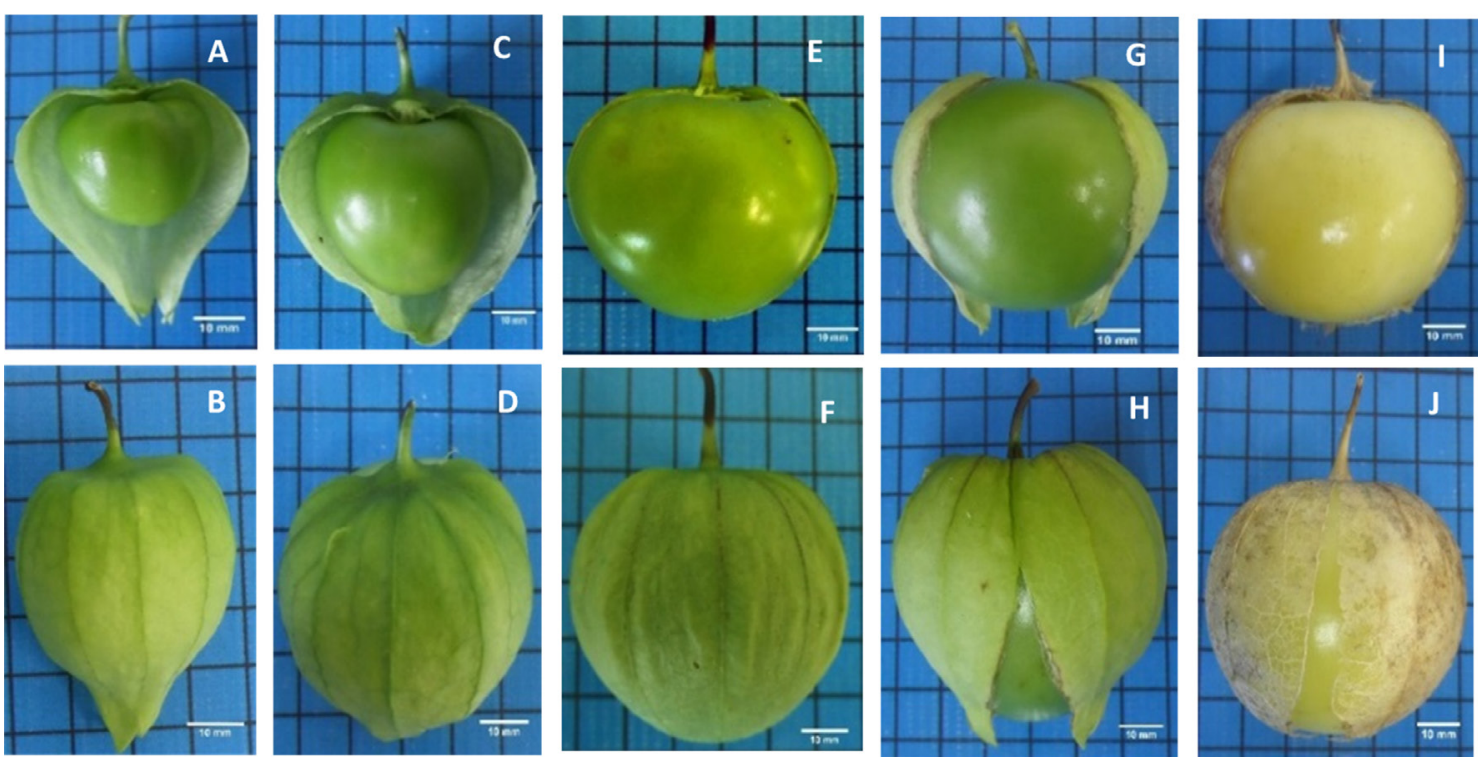

FIGURE 1- Stages of development and maturation of fruits and cup coloring of P. ixocarpa with 15 (A;B), $25(\mathrm{C} ; \mathrm{D}), 35(\mathrm{E} ; \mathrm{F}), 45(\mathrm{G} ; \mathrm{H})$ and $55(\mathrm{~J} ; \mathrm{I})$ days after anthesis.

Source: Author's photos. 
A
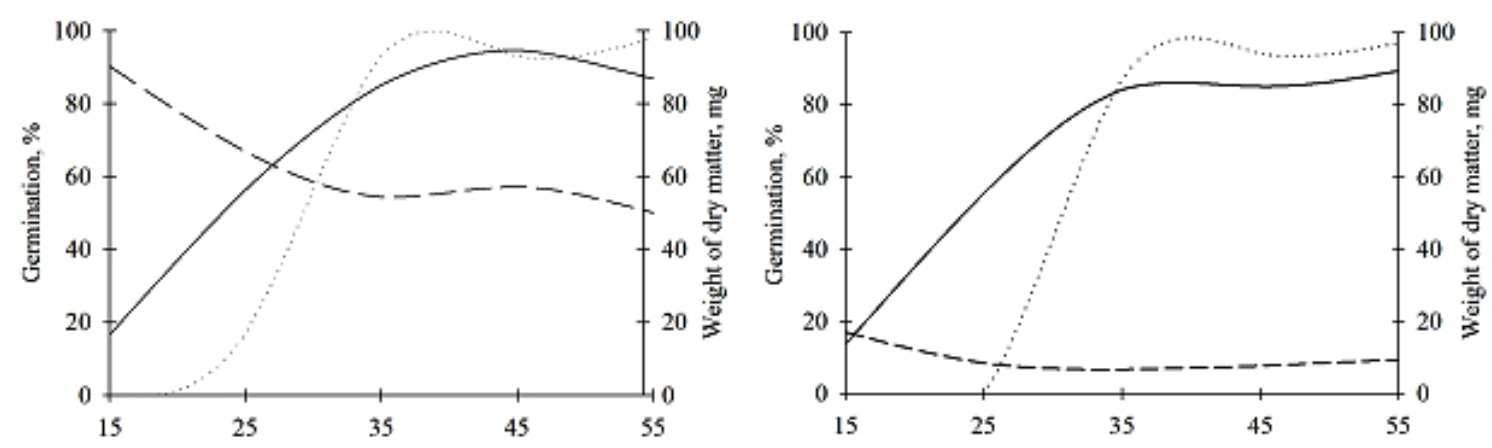

FIGURE 2- Germination (\%) (.......), water content (\%) (_ _ - ) and weight of dry matter (mg) (_ (A) and dry (B) seeds in different stages of development of $P$. ixocarpa fruits.

$25 \mathrm{DAA}$
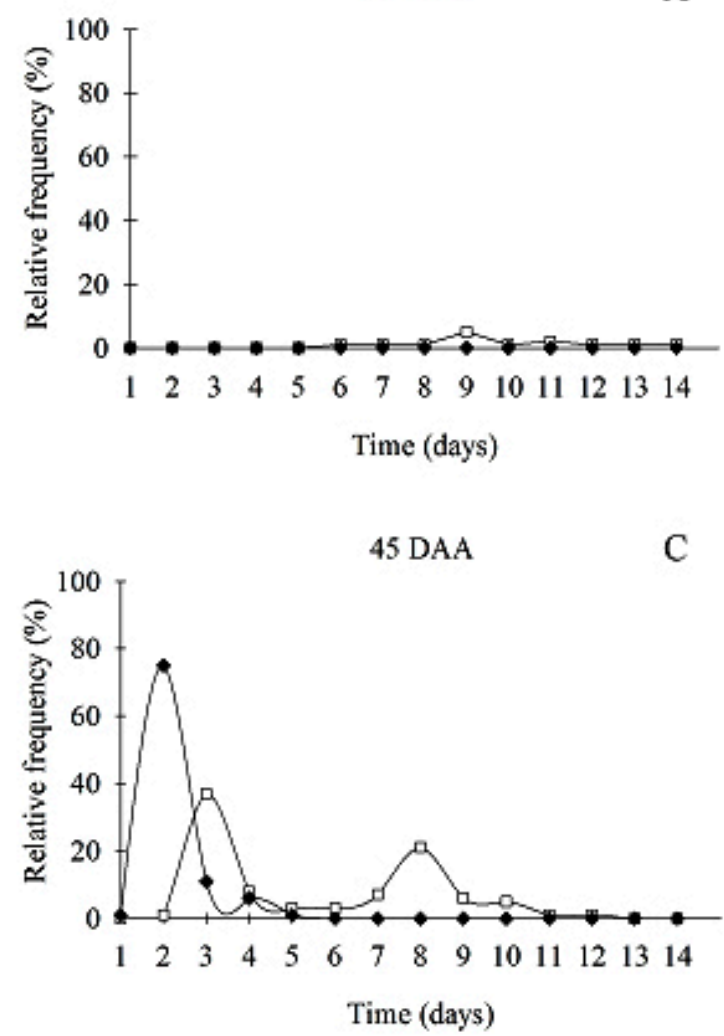

A

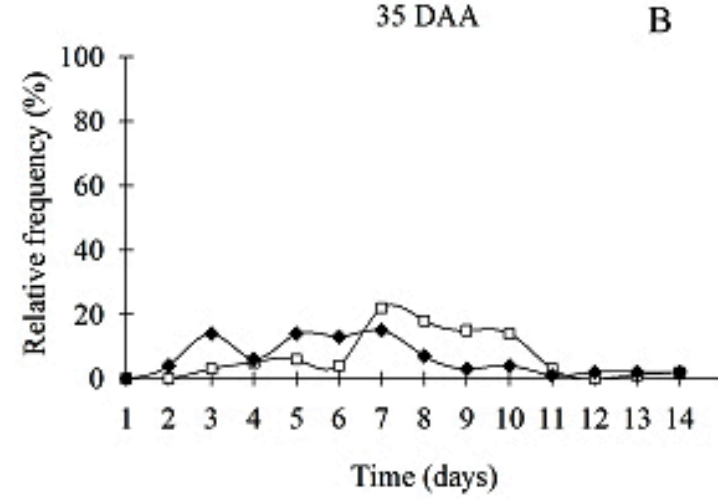

55 DAA

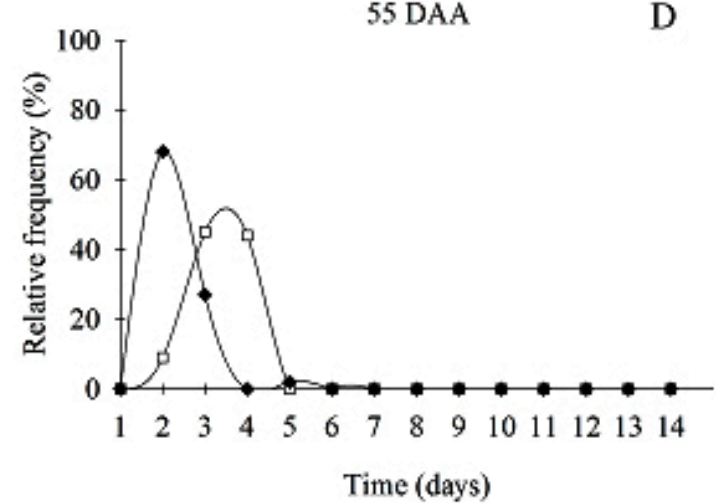

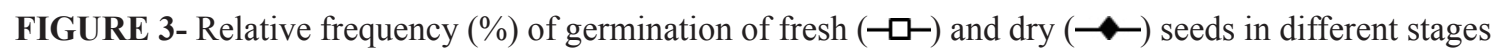
of development of $P$. ixocarpa fruits. 


\section{CONCLUSION}

P. ixocarpa seeds of higher physiological quality were achieved with 45 days after anthesis and can be harvested when the cup becomes disruption and predominantly yellowish-green and dark-green fruits. On the other hand, the fruits intended for use as vegetables due to its physic-chemical characteristics shall be harvested 35 days after anthesis.

\section{REFERENCES}

AIZAT, W.M.; DIAS, D.A.; STANGOULIS, J.C.R.; ABLE, J.A.; ROESSNER, U.; ABLE, A.J. Metabolomics of capsicum ripening reveals modification of the ethylene related-pathway and carbon metabolism. Postharvest Biology and Technology, Amsterdam, v.89, p.19-31, 2014.

ARAUJO J.C.; SILVA, P.P.M.; TELHADO, S.F.P.; SAKAI, R.H.; SPOTO, M.H.F.; MELO, P.C.T.Physico-chemical and sensory parameters of tomato cultivars grown in organic systems. Horticultura Brasileira, Vitoria da Conquista, v.32, n.2, p.205-209, 2014.

BALAGUERA-LOPEZ, H.E.; MARTINEZ C., C.A.; HERRERA-AREVALO, A. Papel del cáliz en el comportamiento poscosecha de frutos de uchuva (Physalis peruviana L.) ecotipo Colombia. Revista Colombiana de Ciencias Hortículas, Bogotá, v.8, n.2, p.181-191, 2014.

BOCK, M.A.; SANCHEZ-PILCHER, J.; MCKEE, L.J.; ORTIZ, M. Selected nutritional and quality analyses of tomatillos (Physalis ixocarpa).Plant Foods for Human Nutrition, Dordrecht, v.48, n.2, p.127-133, 1995.

CALZADA-LÓPEZ, S.G.C.; SHIBATA, J.K.; MORTERA, E.U.; ESTEVA, A.G.; JIMÉNEZ, P.Y. Temperaturas cardinales y velocidad de germinación en cultivares de tomate de cáscara. Revista Mexicana de Ciencias Agrícolas, Texcoco, v.8, p.1451-1458, 2014.

CANTWELL, M.; FLORES-MINUTTI, A.; TREJO-GONZALEZ, A. Developmental changes and postharvest physiology of tomatillo fruits (Physalis ixocarpa Brot.). Scientia Horticulturae, Amsterdam, v.50, n.1-2, p.59-70,1992.
CARVALHO, T.C.; D'ANGELO, J.W.O.; SCARIOT, G.N.; SAES JÚNIOR, L.A.; CUQUEL, F.L. Germinação de sementes de Physalis angulata L.: estádio de maturação do cálice e forma de armazenamento. Pesquisa Agropecuária Tropical, Goiânia, v.44, n.4, p.357-362, 2014.

CRUZ-ÁLVAREZ, O.; MARTÍNEZ-DAMIÁN, M.T.; RODRÍGUEZ-PÉREZ, J.E.; COLINASLEÓN, M.T.; MORENO-PÉREZ, E.C. Conservación poscosecha de tomate de cáscara (Physalis ixocarpa Brot.ex Horm.) con y sin cáliz. Revista Chapingo Serie Horticultura, Chapingo, v.18, n.3, p.333-344, 2012.

CRUZ, A.C.F.; SANTOS, R.P.; IAREMA, L.; FERNANDES, K.R.G.; KUKI, K.N.; ARAÚJO, R.F.; OTONI, W.C. Métodos comparativos na extração de pigmentos foliares de três híbridos de Bixa orellana L. Revista Brasileira de Biociências, Porto Alegre, v.5, n.2, p.777-779, 2007.

DKHIL M.A.; AL-QURAISHY S.; DIAB M.M.; OTHMAN M.S.; AREF A.M.; ABDEL MONEIM A.E. The potential protective role of Physalis peruviana L.fruit in cadmium-induced hepatotoxicity and nephrotoxicity. Food and Chemical Toxicology, Oxford, v.74, p.98-106, 2014.

UEFS - Universidade Estadual de Feira de Santana. Estação Climatológica. UEFS/DTEC/INMET. (n.83221). Disponível em: <http://www.uefs.br/ estacaoclimatologica/climafeira.html $>$ Acesso em: 19 maio 2015.

FERREIRA, D.F. Sisvar: a computer statistic alanalysis system. Ciência e Agrotecnologia, Lavras, v.35, n.6, p.1039-1042, 2011.

FISCHER, G.; ALMANZA-MERCHÁN, P.J.A; MIRANDA, D.Importancia y cultivo de la uchuva (Physalis peruviana L.) Revista Brasileira de Fruticultura, Jaboticabal, v.36, n.1, p.1-15, 2014.

ISTA - International Seed Testing Association. International rules for seed testing association. Bassersdorf, 2007. p.248.

JIMÉNEZ-SANTANA, E.; ROBLEDO-TORRES, V.; BENAVIDES-MENDOZA, A.; RAMÍREZGODINA, F.; RAMÍREZ-RODRÍGUEZ, H.; CRUZLÁZARO, E de la. Calidad de fruto de genotipos tetraploides de tomate de cáscara (Physalis ixocarpa Brot.) Universidad y Ciencia, Villahermosa, v.28, n.2, p.153-161, 2012. 
JUSTINO, E.V.; BOITEUX, L.S.; FONSECA, M.E.N.; SILVAFILHO, J.G.; NASCIMENTO, W.M. Determinação da maturidade fisiológica de sementes de pimenta dedo de moça Capsicum baccatum var. pendulum. Horticultura Brasileira, Vitoria da Conquista, v.33, n.3, p.324-331, 2015.

KHAN, W.; BAKHT, J.; SHAFI, M. Antimicrobial potentials of different solvent extracted samples from Physalis ixocarpa. Pakistan Journal of Pharmaceutical Sciences, Karachi, v.29, n.2, p.467475, 2016.

KONG, Q.; MAO, P.S.; YU, X.D.; XIA, F.S. Physiological changes in oat seeds aged at different moisture contents. Seed Science and Technology, Zurich, v.42, n.2, p.190-201, 2014.

MALDONADO, E.; PÉREZ-CASTORENA, A.L.; GARCÉS, C.; MARTÍNEZ, M. Philadelphica lactones $\mathrm{C}$ and $\mathrm{D}$ and other cytotoxic compounds from Physalis philadelphica. Steroids, New York, v.76, n.7, p.724-728, 2011.

MUNIZ, J.; KRETZSCHMAR, A.A.; RUFATO, L.; PELIZZA, T.R.; MARCHI, T.; DUARTE, A.E.; LIMA, A.P.F.; GARANHANI, F. Sistemas de condução para o cultivo de Physalis no planalto catarinense. Revista Brasileira de Fruticultura, Jaboticabal, v.33, n.3, p.830-838, 2011.

OLIVEIRA, J.A.R.; MARTINS, L.H.S.; VASCONSELOS, M.A.M.; PENA, R.S.; CARVALHO, A.V. Caracterização física, físicoquímica e potencial tecnológico de frutos de camapu (Physalis angulata L.). Revista Brasileira de Tecnologia Agroindustrial, Paraná, v.5, n.2, p.573583, 2011.

PEREZ-CAMACHO, I.; GONZÁLEZHERNÁNDEZ, V.A.; MOLINA-MORENO, J.C.; AYALA-GARAY, O.J.; PEÑA-LOMELÍ, A. Efecto de desarrollo y secado de semillas de physalis ixocarpa brot en germinación, vigor y contenido de azúcares. Interciencia, Caracas, v.33, n.10, p.762766, 2008.

PICHARDO-GONZALEZ, J.M.; AYALA-GARAY, O.J.; GONZALEZ-HERNANDEZ, V.A.; FLORESORTIZ, C.M. Fatty acids and physiological quality of tomatillo (Physalis philadelphica Lam.) seed during natural ageing. Chilean Journal of Agricultural Research, Chillán, v.74, n.4, p.391-396, 2014.
RODRÍGUEZ-BURGOS, A.; GARAY, O.J.A.; LIVERA, A.H.; LEÓN, V.M.L.; MONDACA, E.C. Desarrollo de fruto y semilla de cinco variedades de tomate de cáscara en Sinaloa. Revista Mexicana de Ciencias Agrícolas, Texcoco, v.2, n.5, p.673687, 2011.

RODRIGUES, F.A.; PENONI, E.S.; SOARES, J.D.R.; SILVA, R.A.L.; PASQUAL, M. Caracterização física, química e físico química de Physalis cultivada em casa de vegetação. Ciência Rural, Santa Maria, v.44, n.8, p.1411-1414, 2014.

SANTIAGUILLO-HERNANDEZ, J.F.S.; YANEZ, S.B. Aprovechamiento tradicional de las especies de Physalis en México. Revista de Geografía Agrícola, Chapingo, v.43, p.81-86, 2009.

SBRUSSI, C.A.G.; ZUCARELI, C.; PRANDO, A.M.; SILVA, B.V.A.B. Maturation stages of fruit development and physiological seed quality in Physalis peruviana. Revista Ciência Agronômica, Fortaleza, v.45, n.3, p.543-549, 2014.

SOUZA, M.O.; SOUZA, C.L.M.; PELACANI, C.R. Germinação de sementes osmocondicionadas e não osmocondicionadas e crescimento inicial de Physalis angulata L.(Solanaceae) em ambientes salinos. Acta Botanica Brasilica, Feira de Santana, v.25, n.1, p.105-112, 2011.

SOUZA, M.O.; SOUZA, C.L.M.; BARROSO, N.S.; PELACANI, C.R. Preconditioning of Physalis angulata L.to maintain the viability of seeds. Acta Amazonica, Manaus, v.44, n.1, p.153-156.2014.

\section{ROYAL HORTICULTURAL SOCIETY. RHS} colour chart. London, 2001.

WALTERS, C. Orthodoxy, recalcitrance and inbetween: describing variation in seed storage characteristics using threshold responses to water loss. Planta, Berlin, v.242, n.2, p.397-406, 2015.

WELLBURN, A.R. The spectral determination of chlorophylls a and $\mathrm{b}$, as well as total carotenoids, using various solvents with spectrophotometers of different resolution. Journal of Plant Physiology, Stuttgart, v.144, n.3, p.307-313, 1994. 